\title{
Effects of C-peptide on blood flow, capillary diffusion capacity and glucose utilization in the exercising forearm of Type 1 (insulin-dependent) diabetic patients
}

\author{
B.-L.Johansson, B. Linde and J. Wahren \\ Department of Clinical Physiology, Karolinska Hospital, Karolinska Institute, Stockholm, Sweden
}

\begin{abstract}
Summary. Microvascular dysfunction is frequently seen in patients with Type 1 (insulin-dependent) diabetes. The present study was undertaken to examine whether skeletal muscle microcirculation in Type 1 diabetic patients is influenced by C-peptide. Forearm blood flow, capillary diffusion capacity and substrate exchange were studied during strenuous rhythmic forearm exercise on a hand ergometer. Measurements were made before and during $i$. v. infusion for 60 min of C-peptide or $0.9 \% \mathrm{NaCl}$ in Type 1 diabetic patients and healthy subjects. During infusion the C-peptide levels in the diabetic patients increased from less than $0.05 \mathrm{nmol} / \mathrm{l}$ to $1.32 \pm 0.08 \mathrm{nmol} / \mathrm{l}$. Prior to infusion forearm blood flow and capillary diffusion capacity during exercise were lower in the diabetic patients than the control subjects. During C-peptide infusion both variables increased in the diabetic patients (blood flow $+27 \pm 4 \%$, capillary diffusion capacity $+52 \pm 9 \%$ ) to levels similar to those in the healthy subjects, while no significant change was seen in the healthy control subjects or the diabetic patients given $\mathrm{NaCl}$. Forearm uptake
\end{abstract}

of oxygen and glucose in the diabetic patients increased markedly after C-peptide administration but were unchanged after NaCl infusion. Significant uptake of C-peptide to the deep forearm tissues was observed in the resting state; approximately $7 \pm 2 \%$ of the arterial C-peptide concentration was extracted by forearm tissues in diabetic patients as well as in healthy control subjects. It is concluded that replacement of C-peptide to physiological levels in young Type 1 diabetic patients results in a normalization of both blood flow and capillary diffusion capacity during exercise, as well as augmented uptake of oxygen and glucose by exercising muscle. The findings suggest that C-peptide may be of importance for microvascular function in exercising muscle in Type 1 diabetes. Finally, skeletal muscle is a major site of C-peptide disposal.

Key words: Hand ergometer, indicator-diffusion technique, lactate exchange, oxygen uptake, skeletal muscle, substrate exchange, vascular resistance.
Since the discovery that proinsulin is split into insulin and C-peptide in the Golgi apparatus of the Beta cells [1, 2], Cpeptide has been considered to be without physiological effects of its own. Only a few early studies have attempted to document biological effects of C-peptide. They concerned possible insulin-like effects in fat cells and were consistently negative [3-6]. More recently, however, it has been established that short-term intravenous infusion of physiological amounts of C-peptide in patients with Type 1 (insulin-dependent) diabetes mellitus significantly reduces the glomerular hyperfiltration $[7,8]$ and increases the whole body glucose turnover [7,9]. Subsequent studies using an in vitro model have confirmed that C-peptide has the capacity to stimulate glucose transport into skeletal muscle [10]. These findings prompted a clinical pilot study in which Type 1 diabetic patients were given either subcutaneous C-peptide plus insulin or insulin alone for one month [8]. The C-peptide-treated patients showed a reduced glomerular filtration rate, in accordance with the results from short-term C-peptide administration. In addition, diminished urinary albumin excretion and an improvement in metabolic control, as evidenced by reduced levels of fructosamine and glycated haemoglobin, were observed in the C-peptide-treated group [8].

The above results suggest that, contrary to the prevailing view, C-peptide may in fact possess biological effects and that these may be studied more readily in Type 1 diabetic patients lacking endogenous C-peptide, than in healthy subjects. Specifically, the observed effects of Cpeptide on glomerular filtration and urinary protein excretion raise the possibility that C-peptide may exert an influence on microvascular function, in particular capillary permeability. Consequently, in the present study the influence of C-peptide administration on skeletal muscle blood flow, capillary permeability and substrate exchange has been examined in Type 1 diabetic patients. 
Table 1. Clinical data for Type 1 (insulin-dependent) diabetic patients and healthy control subjects

\begin{tabular}{|c|c|c|c|c|c|c|c|c|}
\hline & \multirow[t]{3}{*}{$n$} & \multirow{3}{*}{$\begin{array}{l}\text { Age } \\
\text { (years) }\end{array}$} & \multirow{3}{*}{$\begin{array}{l}\mathrm{BMI} \\
\left(\mathrm{kg} / \mathrm{m}^{2}\right)\end{array}$} & \multirow{3}{*}{$\begin{array}{l}\text { Duration of } \\
\text { diabetes } \\
\text { (years) }\end{array}$} & \multirow{3}{*}{$\begin{array}{l}\text { Insulin dosage } \\
\left(\mathrm{IU} \cdot \mathrm{kg}^{-1} \cdot 24 \mathrm{~h}^{-1}\right)\end{array}$} & \multirow{3}{*}{$\begin{array}{l}\mathrm{HbA}_{1 \mathrm{c}} \\
\%\end{array}$} & \multicolumn{2}{|c|}{ Blood Pressure } \\
\hline & & & & & & & Systolic & Diastolic \\
\hline & & & & & & & $(\mathrm{mm} \mathrm{Hg})$ & \\
\hline Diabetic patients $(\mathrm{NaCl})$ & 11 & $22 \pm 1$ & $24 \pm 1$ & $10 \pm 1$ & $0.81 \pm 0.05$ & $7.7 \pm 0.7$ & $124 \pm 2$ & $71 \pm 2$ \\
\hline Healthy subjects (C-peptide) & 4 & $21 \pm 1$ & $22 \pm 1$ & & & & & \\
\hline
\end{tabular}

Data are given as means $\pm \mathrm{SEM}$

\section{Subjects and methods}

\section{Subjects}

Four groups of subjects were examined, of which two were Type 1 diabetic patients and two were healthy control subjects. C-peptide was infused in one patient and one control group, $\mathrm{NaCl}$ in the other. Clinical data for the groups are presented in Table 1. All subjects were men. Four patients participated in both the C-peptide and the $\mathrm{NaCl}$ group. Concentrations of fasting plasma C-peptide were low in one C-peptide and one $\mathrm{NaCl}$ control patient $(0.18$ and $0.22 \mathrm{nmol} / \mathrm{l}$, respectively) and undetectable in all the others. Two patients were receiving insulin continuously via subcutaneous infusion pumps; all the other patients received short-acting insulin before meals (three to four doses during the day) and one dose of intermediate-acting insulin at bedtime. All patients were normotensive and presented no clinical evidence of retinopathy, neuropathy or nephropathy. All subjects were informed of the nature, purpose and possible risks of the study before giving their consent to participate. The study protocol was approved by the institutional ethics committee.

\section{Procedure}

An indicator diffusion technique, based on the administration of ${ }^{51} \mathrm{Cr}$-EDTA and indocyanine green $[11,12]$, was employed to determine forearm blood flow and capillary diffusion capacity before and during C-peptide administration or $\mathrm{NaCl}$ infusion.

All subjects came to the laboratory in the morning after an overnight fast. A teflon catheter (internal diameter $0.7 \mathrm{~mm}$ ) was inserted into the brachial artery with the subject in the supine position. Local anaesthesia and percutaneous technique were used and the catheter was advanced $5 \mathrm{~cm}$ in the proximal direction. Another catheter (internal diameter $1.4 \mathrm{~mm}$ ) was inserted into an ipsilateral cubital vein and advanced in the retrograde direction $5-8 \mathrm{~cm}$ into a deep forearm vein. A third catheter was placed in a contralateral cubital vein for infusion of either C-peptide or $\mathrm{NaCl}$. Each subject then performed four 5-min periods of rhythmic ( 1 contraction/s) dynamic exercise on a hand ergometer. A few days before the study, the subjects had visited the laboratory for the determination of a work load on the hand ergometer that would result in near total exhaustion after approximately $5 \mathrm{~min}$ of exercise. The work load was the same in each of the four exercise periods of the study. Period 1 began at 30-40 min after insertion of the catheters and period 2 started 25 min later. Period 3 began after 30 min infusion of synthetic human C-peptide $\left(6 \mathrm{pmol} \cdot \mathrm{kg}^{-1} \cdot \mathrm{min}^{-1}\right.$; Eli Lilly Co, Indianapolis, Ind., USA) or $\mathrm{NaCl}$ and period 4 was started 25 min later.

After $4.5 \mathrm{~min}$ of each exercise period, a $1 \mathrm{ml}$ bolus of two indicators was injected into the brachial artery. The indicators were a nonpermeable intravascular reference substance, $2 \mathrm{mg}$ of albuminbound indocyanine green (Cardio-Green; Becton Dickinson, Cockeysville, Md., USA) and $0.37 \mathrm{MBq}$ of a permeable tracer $\left({ }^{51} \mathrm{CR}\right.$ EDTA; Amersham International, Amersham, Bucks, UK) dissolved in saline. Shortly before the injection, the stopcock of the deep venous catheter was opened and freely streaming blood was collected for $30 \mathrm{~s}$ into a fraction collector, changing tubes every sec- ond. Approximately $1 \mathrm{ml}$ venous blood was collected into heparinized tubes. Blood was sampled simultaneously from the brachial artery and deep venous catheters before and at the end of each exercise period for the analysis of oxygen, haemoglobin, glucose, C-peptide and lactate. Insulin was analysed in blood samples drawn from the brachial artery and haematocrit was determined in blood taken from the deep forearm vein. Intraarterial blood pressure was recorded during each exercise period for $30 \mathrm{~s}$ immediately after the bolus injection of the indicators into the brachial artery.

\section{Calculations}

Blood flow and capillary diffusion capacity were calculated according to Trap-Jensen [12]. Q is the blood flow (in ml blood per min per $100 \mathrm{ml}$ forearm) calculated from the injected amount of indocyanine green (I), the area (A) beneath the dye time-concentration curve and the forearm volume (V) in $\mathrm{ml}$ :

$\mathrm{Q}=\frac{\mathrm{I} \times 100}{\mathrm{~A} \times \mathrm{V}}$

The extraction of permeable tracer, $\mathrm{E}(\mathrm{t})$, in each sample was calculated as:

$E(t)=\frac{C(t)-c(t)}{C(t)}$

where $C(t)$ and $c(t)$ are the relative concentrations of the plasma bound reference (indocyanine green) and the permeable tracer $\left({ }^{51} \mathrm{Cr}-\mathrm{EDTA}\right)$, respectively. The average extraction (E) of ${ }^{51} \mathrm{Cr}-$ EDTA was computed by integration over the time interval during which constant $\mathrm{E}(\mathrm{t})$ values were observed. The capillary diffusion capacity $(\mathrm{CDC})$ is defined as the maximum unidirectional flux of tracer over the capillary membrane per unit concentration difference, and was calculated according to the equation $[11,12]$ :

$\mathrm{CDC}=-\mathrm{k} \times \mathrm{Q} \times \ln (1-\mathrm{E}) \times(1-$ haematocrit $)$;

and expressed in $\mathrm{ml} \cdot \mathrm{min}^{-1} \cdot 100 \mathrm{ml}^{-1}$. The symbol $\mathrm{k}$ is the constant for converting $\mathrm{ml}$ of plasma to $\mathrm{ml}$ of interstitial fluid, and is 0.89 for ${ }^{51}$ Cr-EDTA [12].

Forearm work intensity was calculated from the tension of the spring of the hand ergometer, the path of contraction and the frequency of contraction. The work intensity was expressed in $\mathrm{W} / 100 \mathrm{ml}$ forearm.

Forearm oxygen uptake was determined as the product of arterio-venous oxygen difference and blood flow. The arterio-venous oxygen difference was calculated from the deep venous oxygen saturation and the measured haemoglobin concentration. The arterial blood oxygen saturation was assumed to be $98 \%$. Forearm lactate release and glucose uptake were calculated as the product of the arterio-venous concentration differences and the blood flow.

\section{Analytical procedures}

Indocyanine green dye was determined spectrophotometrically (Hitachi U 2000; Hitachi Ltd., Tokyo, Japan) at $805 \mathrm{~nm}$ and ${ }^{51} \mathrm{Cr}$ radioactivity was measured using a gamma counter (Compu Gamma 

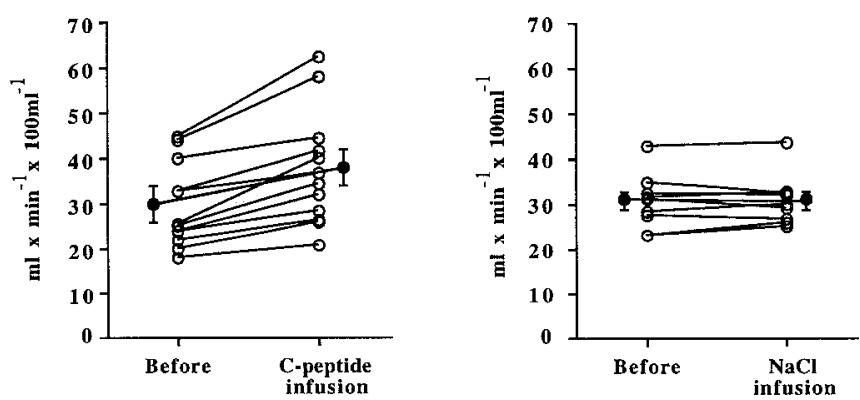

Fig. 1. Individual data for forearm blood flow during exercise in Type 1 (insulin-dependent) diabetic patients before and during C-peptide (left panel) or $\mathrm{NaCl}$ (right panel) infusion (mean values \pm SEM are represented by the filled circles and bars). Blood flow increased significantly during C-peptide infusion $(p<0.001)$ but was unaltered during $\mathrm{NaCl}$ infusion

counter, Mod 1282; LKB Wallac Oy, Turku, Finland) in $100 \mu$ l blood samples in duplicate after dilution in distilled water (1:6). Oxygen saturation was measured spectrophotometrically (OSM 3 Hemioximeter; Radiometer, Copenhagen, Denmark). Haematocrit was determined by means of a microcapillary centrifuge after 5 min centrifugation at $11,500 \mathrm{rev} / \mathrm{min}$ and corrected for trapped plasma according to Garby and Vuille [13]. $\mathrm{HbA}_{1 \mathrm{c}}$ was measured by an ion chromatography procedure using microcolumns (Mono S HR 5/5; Pharmacia, Uppsala, Sweden). C-peptide in plasma was analysed using a radioimmunoassay technique [14] and a commercial kit (Cpeptide RB-315; MILAB, Malmö, Sweden). Plasma free insulin was assayed with a radioimmunological technique after precipitation with $25 \%$ polyethylene glycol [15]. Blood glucose and lactate concentrations were analysed in whole blood by enzymatic techniques. Intra-arterial blood pressure was recorded using a pressure sensor system (Senso Nor 840; Senso Nor a.s. Horten, Norway). The forearm volume was measured by water displacement, using the distal part of the ulnar styloid process as the lower landmark and the medial epicondylus of the humerus as the upper.

\section{Data presentation}

In most of the subjects, blood flow and tracer extraction were determined two times before $\mathrm{C}$-peptide or $\mathrm{NaCl}$ infusion and two times after. Neither blood flow nor tracer extraction differed between the first and the second measurement, either before or after the C-peptide or $\mathrm{NaCl}$ intervention. Consequently, the first and second measurements were combined, as were the third and fourth, and average values were calculated for each individual. However, technically adequate measurements were not obtained in all patients and control subjects. Thus, single rather than duplicate determinations of blood flow were performed in 7 of 21 patients before C-peptide or $\mathrm{NaCl}$ infusion and in 6 of 21 patients after infusion. Likewise, in the control subjects, single measurements were made in 2 of 15 subjects before intervention and in 6 of 15 after. In the case of tracer extraction, single determinations only were made in 2 of 13 patients both before and after C-peptide or $\mathrm{NaCl}$ infusion.

Glucose and lactate measurements are presented as arterio-venous differences for each of the four exercise periods, since the values for glucose tended to increase and those for lactate to decrease with time and the number of exercise periods. However, data for forearm exchange of glucose and lactate are based on the average value of the two first and the two last exercise periods, respectively.

\section{Statistical analysis}

Standard statistical methods were employed, using paired and unpaired Student's $t$-test, Wilcoxon's sign rank test and analysis of variance (ANOVA) when applicable. Data in the text, figures and tables are given as mean values \pm SEM.

\section{Results}

Blood flow: Forearm blood flow during exercise for all diabetic patients before C-peptide or $\mathrm{NaCl}$ infusion was $29 \pm 2 \mathrm{ml} \cdot \min ^{-1} \cdot 100 \mathrm{ml}^{-1} \quad(n=17)$. The corresponding value for the healthy control subjects was $40 \pm 2 \mathrm{ml}$. $\min ^{-1} \cdot 100 \mathrm{ml}^{-1}(n=14, p<0.001)$. When exercise was repeated during intravenous $\mathrm{C}$-peptide infusion, blood flow was found to have risen in the diabetic patients by $27 \pm 4 \%$ to $38 \pm 4 \mathrm{ml} \cdot \mathrm{min}^{-1} \cdot 100 \mathrm{ml}^{-1}(n=12, p<0.001$, Fig. 1$)$, whereas no significant alteration occurred in the healthy subjects (Table 2). Likewise, $\mathrm{NaCl}$ infusion in diabetic patients as well as healthy control subjects resulted in an unchanged forearm blood flow (Table 2).

Table 2. Forearm blood flow, extraction of permeable tracer, capillary diffusion capacity (CDC), arterial blood pressure and forearm vascular resistance before and during $\mathrm{C}$-peptide or $\mathrm{NaCl}$ infusion in Type 1 (insulin-dependent) diabetic patients and healthy control subjects

\begin{tabular}{|c|c|c|c|c|c|c|c|}
\hline & \multirow{2}{*}{$\begin{array}{l}\text { Blood flow } \\
\left(\mathrm{ml} \cdot \mathrm{min}^{-1} \cdot 100 \mathrm{ml}^{-1}\right)\end{array}$} & \multirow{2}{*}{$\begin{array}{l}\text { Extraction of } \\
\text { permeable tracer } \\
(\%)\end{array}$} & \multirow{2}{*}{$\begin{array}{l}\mathrm{CDC} \\
\left(\mathrm{ml} \cdot \mathrm{min}^{-1}\right. \\
\left.100 \mathrm{ml}^{-1}\right)\end{array}$} & \multicolumn{3}{|c|}{ Blood Pressure } & \multirow{2}{*}{$\begin{array}{l}\text { Resistance } \\
\left(\mathrm{mm} \mathrm{Hg} \cdot \mathrm{ml}^{-1}\right. \\
\left.\mathrm{min}^{-1} \cdot 100 \mathrm{ml}^{-1}\right)\end{array}$} \\
\hline & & & & \multicolumn{2}{|c|}{$\begin{array}{l}\text { Systolic } \\
(\mathrm{mm} \mathrm{Hg})\end{array}$} & Diastolic & \\
\hline & Infusion & Before Infusion & Infusion & Before & Infusion Before & Infusion & Before Infusion \\
\hline $\begin{array}{l}\text { Diabetic patients } \\
\text { (C-peptide) }\end{array}$ & $\begin{array}{l}30 \pm 4 \\
(n=12)\end{array}$ & $\begin{array}{l}31 \pm 4 \quad 35 \pm 4^{c} \\
(n=7)\end{array}$ & $\begin{array}{c}5.3 \pm 0.6 \quad 8.0 \pm 0.9^{b} \\
(n=7)\end{array}$ & $142 \pm 5$ & $\begin{array}{c}131 \pm 3^{\mathrm{c}} \quad 87 \pm 5 \\
(n=7)\end{array}$ & $79 \pm 4^{b}$ & $\begin{array}{c}4.5 \pm 0.6 \quad 3.3 \pm 0.4^{\mathrm{a}} \\
(n=5)\end{array}$ \\
\hline $\begin{array}{l}\text { Diabetic patients } \\
(\mathrm{NaCl})\end{array}$ & $\begin{array}{l}31 \pm 2 \quad 31 \pm 2 \\
\quad(n=9)\end{array}$ & $\begin{array}{l}32 \pm 2 \quad 33 \pm 2 \\
(n=5)\end{array}$ & $\begin{array}{c}6.1 \pm 0.65 .8 \pm 0.6 \\
(n=5)\end{array}$ & $141 \pm 6$ & $\begin{array}{c}142 \pm 6 \quad 83 \pm 5 \\
(n=6)\end{array}$ & $83 \pm 5$ & $\begin{array}{c}3.7 \pm 0.3 \quad 3.6 \pm 0.3 \\
(n=5)\end{array}$ \\
\hline $\begin{array}{l}\text { Healthy subjects } \\
(\mathrm{NaCl})\end{array}$ & $\begin{array}{l}41 \pm 3 \quad 43 \pm 3 \\
(n=10)\end{array}$ & $\begin{array}{l}30 \pm 2 \quad 32 \pm 2 \\
\quad(n=8)\end{array}$ & $\begin{array}{c}8.8 \pm 1.5 \quad 8.1 \pm 0.7 \\
(n=8)\end{array}$ & $140 \pm 4$ & $\begin{array}{c}134 \pm 3^{c} \quad 77 \pm 2 \\
(n=6)\end{array}$ & $74 \pm 3$ & $\begin{array}{c}2.5 \pm 0.42 .4 \pm 0.3 \\
(n=6)\end{array}$ \\
\hline
\end{tabular}

Data under the heading "Before" represent the mean of two measurements before administration of C-peptide or $\mathrm{NaCl}$, while "Infusion" denotes the mean of two measurements obtained at 30 and $60 \mathrm{~min}$ after onset of $\mathrm{C}$-peptide or $\mathrm{NaCl}$ infusion. Data are given as means \pm SEM. ${ }^{\mathrm{a}} p<0.001,{ }^{\mathrm{b}} p<0.01,{ }^{\mathrm{c}} p<0.05$ denote the probability that differences between values before and during C-peptide or $\mathrm{NaCl}$ infusion are caused by random factors 

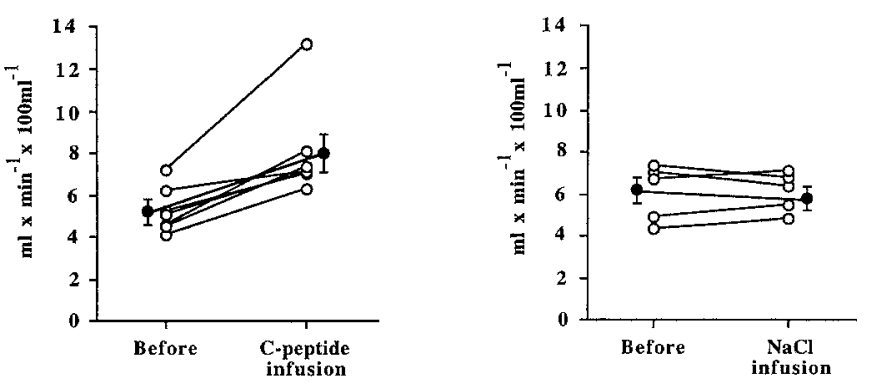

Fig. 2. Individual data for capillary diffusion capacity (CDC) of the exercising forearm before and during $\mathrm{C}$-peptide (left panel) or $\mathrm{NaCl}$ infusion in Type 1 (insulin-dependent) diabetic patients (mean values \pm SEM are represented by the filled circles and bars). CDC increased significantly during C-peptide infusion $(p<0.01)$ but was unaltered during $\mathrm{NaCl}$ infusion
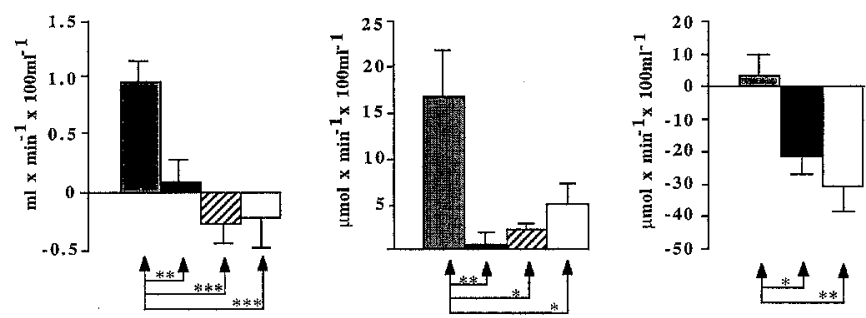

Fig.3. Changes in oxygen uptake (left panel), glucose uptake (middle panel) and lactate release (right panel) of the exercising forearm from the period before infusion to the period of either $\mathrm{C}$ peptide or $\mathrm{NaCl}$ infusion. Diabetic patients receiving C-peptide or $\mathrm{NaCl}$ are indicated by shaded and solid columns, respectively; healthy control subjects given $\mathrm{C}$-peptide or $\mathrm{NaCl}$ are denoted by hatched and open columns, respectively. Mean values \pm SEM are presented. $* * * *<<0.001$, ** $p<0.01, * p<0.05$ denote the probability that differences between the patients receiving C-peptide and the other study groups are caused by random factors

Extraction of permeable tracer: The extraction of the injected permeable tracer $\left({ }^{51} \mathrm{Cr}\right.$-EDTA $)$ in the exercising forearm was found to be similar in diabetic patients and healthy control subjects before infusion of C-peptide or $\mathrm{NaCl}(31 \pm 2$ and $30 \pm 2 \%$, respectively). In the diabetic patients, the extraction of tracer during exercise rose to $35 \pm 4 \%$ during infusion of C-peptide $(p<0.05$, Table 2$)$. When intravenous $\mathrm{NaCl}$ infusion was given instead of $\mathrm{C}$ peptide, neither the patients nor the healthy control subjects showed significant changes in the extraction of the permeable tracer (Table 2).

Capillary diffusion capacity: Forearm CDC during exercise in the diabetic patients before infusion of either Cpeptide or $\mathrm{NaCl}$ was $5.6 \pm 0.4 \mathrm{ml} \cdot \mathrm{min}^{-1} \cdot 100 \mathrm{ml}^{-1}(n=9)$, which was lower than in the healthy control subjects $\left(8.8 \pm 1.5 \mathrm{ml} \cdot \mathrm{min}^{-1} \cdot 100 \mathrm{ml}^{-1}, \quad n=8, \quad p<0.05\right)$. When exercise was repeated in the diabetic patients during intravenous C-peptide infusion, $\mathrm{CDC}$ was found to have risen by $52 \pm 9 \%$ to $8.0 \pm 0.9 \mathrm{ml} \cdot \mathrm{min}^{-1} \cdot 100 \mathrm{ml}^{-1}(n=7$, $p<0.01$, Table 2, Fig. 2). During $\mathrm{NaCl}$ infusion, on the other hand, the CDC of the exercising forearm was unchanged in the diabetic patients as well as in the healthy control subjects (Table 2).
Blood pressure and forearm vascular resistance: The intraarterial blood pressure measured at rest before exercise wassimilar and within the normal range in diabetic patients and healthy control subjects (Table 1). During exercise before infusion of either $\mathrm{C}$-peptide or $\mathrm{NaCl}$, blood pressure increased to the same extent in diabetic patients and control subjects (Table 2). During infusion of C-peptide but not during $\mathrm{NaCl}$ infusion, both systolic and diastolic blood pressures were significantly decreased in the diabetic patients. A similar but less marked tendency was seen in the healthy control subjects after $\mathrm{NaCl}$ infusion.

Forearm vascular resistance during exercise before Cpeptide or $\mathrm{NaCl}$ infusion was for all diabetic patients $4.1 \pm 0.4(n=10)$ compared to $2.5 \pm 0.4 \mathrm{mmHg} \cdot \mathrm{ml}^{-1}$. $\min ^{-1} \cdot 100 \mathrm{ml}^{-1}$ in control subjects $(n=6, p<0.01)$. When exercise was repeated during C-peptide infusion, vascular resistance was found to have decreased in the diabetic patients from $4.5 \pm 0.5$ to $3.3 \pm 0.4 \mathrm{~mm} \mathrm{Hg} \cdot \mathrm{ml}^{-1}$. $\min ^{-1} \cdot 100 \mathrm{ml}^{-1}(-30 \%, p<0.001)$, thus reaching a level not significantly different from that found in the healthy control subjects after $\mathrm{NaCl}$ infusion $(2.4 \pm 0.3 \mathrm{~mm} \mathrm{Hg}$. $\mathrm{ml}^{-1} \cdot \mathrm{min}^{-1} \cdot 100 \mathrm{ml}^{-1}$ ). In the diabetic patients who received $\mathrm{NaCl}$ infusion, forearm vascular resistance remained unaltered.

Forearm oxygen uptake: The arterial-deep venous (ADV) oxygen difference during exercise in the diabetic patients before C-peptide or $\mathrm{NaCl}$ infusion was $130 \pm 6 \mathrm{ml} / \mathrm{l}$ $(n=17)$, which tended to be higher than in the healthy control subjects $(113 \pm 5 \mathrm{ml} / \mathrm{l}, n=14, p<0.1)$. After Cpeptide or $\mathrm{NaCl}$ infusion the A-DV oxygen difference was unchanged in the diabetic patients but fell slightly in the control subjects. Forearm oxygen uptake in the diabetic patients before C-peptide or $\mathrm{NaCl}$ was $3.7 \pm 0.3 \mathrm{ml}$. $\min ^{-1} \cdot 100 \mathrm{ml}^{-1}(n=17)$, which was lower than in the control subjects, $4.6 \pm 0.3 \mathrm{ml} \cdot \mathrm{min}^{-1} \cdot 100 \mathrm{ml}^{-1} \quad(p<0.05$, $n=14$ ). Following C-peptide infusion, forearm oxygen uptake during exercise in the diabetic patients increased by an average of $26 \pm 4 \%$ to $4.6 \pm 0.4 \mathrm{ml} \cdot \mathrm{min}^{-1} \cdot 100 \mathrm{ml}^{-1}$ $(p<0.001$, Fig. 3). In contrast, neither C-peptide administration in healthy control subjects nor $\mathrm{NaCl}$ infusion in diabetic patients or control subjects was accompanied by a statistically significant change in forearm oxygen uptake (Table 3). The haemoglobin concentration was $145 \pm 2 \mathrm{~g} / 1$ in the diabetic patients and $141 \pm 2 \mathrm{~g} / \mathrm{l}$ in the control subjects.

Forearm glucose exchange: The arterial blood glucose concentrations for the four groups are presented in Table 4. During the exercise periods the blood glucose levels remained largely unchanged in all groups (Table 4). The A-DV differences for glucose are shown in Figure 4. Neither the diabetic patients nor the control subjects demonstrated a significant net uptake of glucose before Cpeptide or $\mathrm{NaCl}$ infusion. Following C-peptide infusion, the A-DV glucose difference was markedly increased in the diabetic patients but not in the control subjects (Fig.4). Similar changes were not seen in the diabetic patients or control subjects after $\mathrm{NaCl}$ infusion. Forearm glucose uptake in the diabetic patients increased markedly during C-peptide infusion and was approximately 
Table 3. Forearm exchanges of oxygen, glucose and lactate during exercise before and during C-peptide or $\mathrm{NaCl}$ infusion

\begin{tabular}{|c|c|c|c|c|c|c|}
\hline & \multicolumn{2}{|c|}{$\begin{array}{l}\text { Oxygen uptake } \\
\left(\mathrm{ml} \mathrm{O}_{2} \cdot \mathrm{min}^{-1} \cdot 100 \mathrm{ml}^{-1}\right)\end{array}$} & \multicolumn{2}{|c|}{$\begin{array}{l}\text { Glucose exchange } \\
\left(\mu \mathrm{mol} \cdot \mathrm{min}^{-1} \cdot 100 \mathrm{ml}^{-1}\right)\end{array}$} & \multicolumn{2}{|c|}{$\begin{array}{l}\text { Lactate exchange } \\
\left(\mu \mathrm{mol} \cdot \mathrm{min}^{-1} \cdot 100 \mathrm{ml}^{-1}\right)\end{array}$} \\
\hline & Before & Infusion & Before & Infusion & Before & Infusion \\
\hline Diabetic patients $(\mathrm{NaCl})$ & \multicolumn{2}{|c|}{$(n=9)$} & \multicolumn{2}{|c|}{$(n=8)$} & \multicolumn{2}{|c|}{$(n=5)$} \\
\hline Healthy subjects $(\mathrm{NaCl})$ & \multicolumn{2}{|c|}{$(n=10)$} & \multicolumn{2}{|c|}{$(n=9)$} & \multicolumn{2}{|c|}{$(n=6)$} \\
\hline
\end{tabular}

Data under the heading "Before" represent the mean of two measurements before administration of C-peptide or $\mathrm{NaCl}$, while "Infusion" denotes the mean of two measurements obtained at 30 and $60 \mathrm{~min}$ after onset of $\mathrm{C}$-peptide or $\mathrm{NaCl}$ infusion. Data are presented as means \pm SEM. ${ }^{a} p<0.001,{ }^{b} p<0.01,{ }^{c} p<0.05$ denote the probability that differences between values before and during C-peptide or $\mathrm{NaCl}$ infusion are caused by random factors

Table 4. Arterial concentrations of glucose, lactate and insulin during forearm exercise before and during infusion of $\mathrm{C}$-peptide or $\mathrm{NaCl}$

\begin{tabular}{|c|c|c|c|c|c|c|}
\hline & \multicolumn{2}{|c|}{ Glucose $(\mathrm{mmol} / \mathrm{l})$} & \multicolumn{2}{|c|}{ Lactate (mmol/l) } & \multicolumn{2}{|c|}{ Insulin $(\mu \mathrm{U} / \mathrm{ml})$} \\
\hline & Before & Infusion & Before & Infusion & Before & Infusion \\
\hline Diabetic patients (C-peptide) & \multicolumn{2}{|c|}{$(n=14)$} & \multicolumn{2}{|c|}{$\begin{array}{c}0.79 \pm 0.08 \underset{(n=6)}{0.72 \pm 0.06} \\
(n+10\end{array}$} & \multicolumn{2}{|c|}{$(n=6)$} \\
\hline Diabetic patients $(\mathrm{NaCl})$ & \multicolumn{2}{|c|}{$(n=11)$} & \multicolumn{2}{|c|}{$(n=6)$} & \multicolumn{2}{|c|}{$(n=6)$} \\
\hline Healthy subjects (C-peptide) & \multicolumn{2}{|c|}{$(n=4)$} & - & -- & - & - \\
\hline Healthy subjects $(\mathrm{NaCl})$ & $4.9 \pm 0.1$ & 3) $4.9 \pm 0.1$ & $0.78 \pm 0.09$ & $\begin{array}{l}0.78 \pm 0.08 \\
7)\end{array}$ & $5.1 \pm 0.4$ & $5.1 \pm 0.3$ \\
\hline
\end{tabular}

Data under the heading "Before" represent the mean of two measurements before administration of C-peptide or NaCl, while "Infusion" denotes the mean of two measurements obtained at 30 and 60 min after onset of C-peptide or $\mathrm{NaCl}$ infusion. Data are given as means $\pm \mathrm{SEM}$

three-fold higher than in the diabetic patients given $\mathrm{NaCl}$ (Table 3, Fig.3). A positive relationship was found between the rise in CDC and the increase in A-DV for glucose after C-peptide administration in the diabetic patients $(r=0.88, p<0.001)$.

Forearm lactate exchange: The arterial lactate concentrations were similar in all groups both before and during Cpeptide or $\mathrm{NaCl}$ infusion (Table 4 ). The deep venous-arterial (DV-A) lactate difference was also similar in all groups prior to and during $\mathrm{C}$-peptide or $\mathrm{NaCl}$ infusion but did tend to be higher for the diabetic patients who received $\mathrm{C}$-peptide (Fig. 5). In the latter group, forearm lactate production remained unchanged after C-peptide administration, whereas it fell significantly after $\mathrm{NaCl}$ in the diabetic patients as well as the healthy control subjects (Fig. 5).

Free insulin: The arterial plasma insulin levels during exercise were $7.4 \pm 0.9$ and $6.9 \pm 0.4 \mu \mathrm{U} / \mathrm{ml}$ in the patients before infusion of C-peptide and $\mathrm{NaCl}$, respectively. Free insulin levels were largely unchanged during the C-peptide or $\mathrm{NaCl}$ infusion periods. In the healthy control subjects the corresponding values were $5.1 \pm 0.4$ and $5.1 \pm 0.3 \mu \mathrm{U} / \mathrm{ml}$ before and during $\mathrm{NaCl}$ infusion, respectively, with no significant difference from those in the diabetic patients.
C-peptide concentration: The mean venous C-peptide concentration in the diabetic patients increased from less than 0.05 at rest to $1.32 \pm 0.08 \mathrm{nmol} / 1$ after $60 \mathrm{~min}$ of $\mathrm{C}$ peptide infusion. In the patients receiving $\mathrm{NaCl}$ the level was less than $0.05 \mathrm{nmol} / \mathrm{l}$ throughout the study. In the healthy control subjects the concentration of C-peptide was $0.56 \pm 0.11 \mathrm{nmol} / 1$ at rest and increased to $1.56 \pm 0.22 \mathrm{nmol} / 1$ after $60 \mathrm{~min}$ of C-peptide infusion $(p<0.001)$. Plasma venous $\mathrm{C}$-peptide levels at rest in the healthy control subjects receiving $\mathrm{NaCl} \quad(0.51 \pm$ $0.04 \mathrm{nmol} / \mathrm{l})$ did not change significantly during $60 \mathrm{~min}$ of $\mathrm{NaCl}$ infusion $(0.53 \pm 0.04 \mathrm{nmol} / \mathrm{l})$. Arterial C-peptide concentration and A-DV difference for C-peptide are presented in Figure 6. During $\mathrm{C}$-peptide infusion in the diabetic patients, a positive A-DV difference for C-peptide was observed under resting conditions $(0.08 \pm$ $0.02 \mathrm{nmol} / \mathrm{l})$; the forearm fractional extraction for C-peptide was $7 \pm 2 \%$. In blood samples obtained at the end of the exercise periods the A-DV difference became negative $(-0.05 \pm 0.01 \mathrm{nmol} / 1)$, indicating release of C-peptide from forearm tissues. Similar conditions obtained in the healthy subjects; a positive A-DV difference for C-peptide was observed at rest $(0.04 \pm 0.01 \mathrm{nmol} / 1)$ and the fractional extraction was $7 \pm 2 \%$. During exercise the C-peptide A-DV difference also became negative $(-0.02 \pm$ $0.005 \mathrm{nmol} / \mathrm{l})$ in the healthy control subjects. 


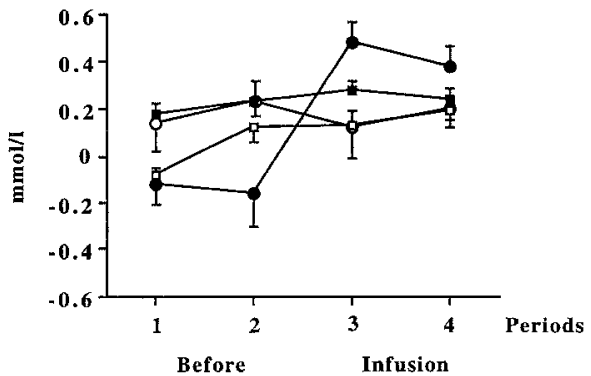

Fig.4. Arterio-deep venous (A-DV) glucose concentration difference for the exercising forearm determined two times before and two times during infusion of $\mathrm{C}$-peptide or $\mathrm{NaCl}$. Type 1 (insulin-dependent) diabetic patients receiving $\mathrm{C}$-peptide or $\mathrm{NaCl}$ are represented by closed and open circles, respectively; healthy control subjects given $\mathrm{C}$-peptide or $\mathrm{NaCl}$ are represented by closed and open squares, respectively. During C-peptide infusion a marked increase in A-DV glucose concentration difference was noted in the diabetic patients $(p<0.001)$, whereas no change was found in the patients receiving $\mathrm{NaCl}$

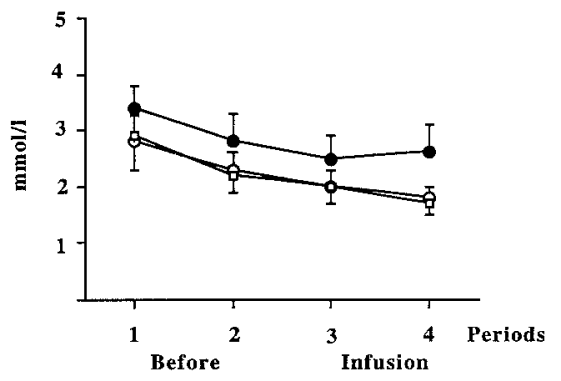

Fig.5. Deep venous-arterial (DV-A) lactate concentration difference for the exercising forearm determined two times before and two times during infusion of either $\mathrm{C}$-peptide or $\mathrm{NaCl}$. Type 1 (insulin-dependent) diabetic patients given $\mathrm{C}$-peptide or $\mathrm{NaCl}$ are represented by closed and open circles, respectively; healthy control subjects receiving $\mathrm{NaCl}$ are represented by open squares. All groups showed a small, gradual decline in the DV-A lactate concentration difference during the repeated periods of forearm exercise $(p<0.05$, ANOVA)

Work intensity and forearm volume: All subjects performed rhythmic exercise on a hand ergometer. The work intensity was $0.60 \mathrm{~W} / 100 \mathrm{ml}$ forearm tissue in both patients and healthy control subjects. The forearm volume was $1090 \pm 30 \mathrm{ml}$ in the diabetic patients and $1030 \pm 40 \mathrm{ml}$ in the healthy control subjects.

\section{Discussion}

This study demonstrates for the first time that C-peptide administration is accompanied by significant haemodynamic and metabolic effects in exercising skeletal muscle in C-peptide negative diabetic patients. In the diabetic subjects, blood flow and the $\mathrm{CDC}$ of the exercising forearm were approximately $30 \%$ lower initially compared to age- and sex-matched healthy control subjects. During intravenous C-peptide administration in the patients, resulting in a rise in C-peptide concentration to physiological levels (approximately $1 \mathrm{nmol} / \mathrm{l}$ ), both blood
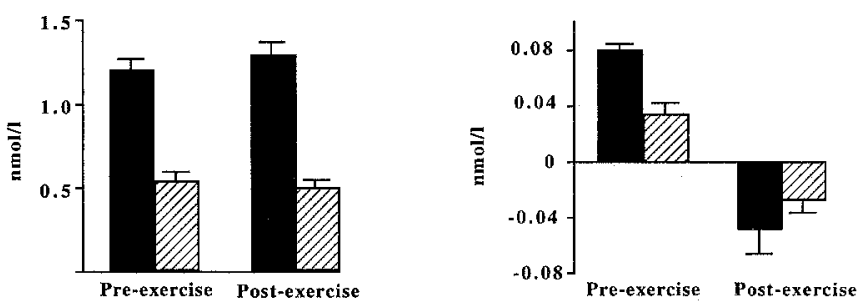

Fig.6. Arterial C-peptide concentrations (left panel) and arteriodeep venous (A-DV) C-peptide concentration differences (right panel) in the Type 1 (insulin-dependent) diabetic patients during $C$ peptide infusion at steady state (black columns) and in healthy control subjects receiving $\mathrm{NaCl}$ (cross hatched columns) before and immediately after forearm exercise. A significant uptake of C-peptide over the forearm was noted in both diabetic patients and healthy control subjects in the resting state $(p<0.01)$. Immediately after exercise C-peptide was released to the deep venous blood in both the diabetic patients $(p<0.05)$ and the healthy control subjects $(p<0.01)$

flow and CDC rose to values similar to those for the healthy control subjects. This was a consistent finding, all patients showing a similar response. In contrast, in the healthy control subjects, whose blood flow and CDC were already higher than in the diabetic patients before the infusion, C-peptide exerted no significant influence on blood flow. Likewise, $\mathrm{NaCl}$ infusion in the diabetic patients did not influence either forearm blood flow or CDC. These findings are consistent with the view that in C-peptide negative diabetic patients, replacement of this peptide elicits microcirculatory effects, while in healthy subjects C-peptide increments above the endogenous basal concentration has no effect. These results are analogous to the previous observations regarding the effect of $\mathrm{C}$ peptide on glucose transport in skeletal muscle; a stimulatory effect of C-peptide is readily demonstrable up to a concentration of $1 \mathrm{nmol} / 1$, but no further effects are seen for higher C-peptide concentrations [10].

The arteriolar dilatation and the increase in blood flow in exercising forearm muscle were accompanied by an increase in the $\mathrm{CDC}$ in the $\mathrm{C}$-peptide-treated diabetic patients. CDC expresses the total unidirectional flux of tracer over the exchange vessels and is thus a reflection not only of the number of perfused capillaries (capillary surface area), which is regulated by the precapillary sphincters, but also of the permeability per unit surface area of the capillary membrane (capillary permeability). Measurements of CDC for one tracer molecule only cannot show whether the enhanced CDC in the C-peptidetreated diabetic patients reflects an increase in the number of perfused capillaries, an increase in the vascular permeability per se, or a combination of the two. The finding that the forearm muscle extraction of ${ }^{51} \mathrm{Cr}$-EDTA was elevated during C-peptide administration in conjunction with a marked rise in blood flow suggests the possibility that capillary permeability may have increased. On the other hand, the diabetic patients receiving C-peptide also displayed a rise in forearm uptake of oxygen and glucose, as well as a relatively greater production of lactate by the forearm tissues. Since neither oxygen nor glucose or lac- 
tate are likely to be restricted in their passage over the capillary membrane, it seems unlikely that an increase in the capillary permeability alone would enhance their uptake or release. The more probable explanation is that Cpeptide administration resulted in an increase in recruitment of capillaries in the muscle. The significant relationship between the increase in CDC and the rise in glucose uptake during C-peptide infusion in the diabetic patients supports this possibility. Thus, the present circulatory and metabolic results taken together are compatible with the view that $\mathrm{C}$-peptide increases the perfusion to compartments within the exercising skeletal muscle, which may have been perfused poorly or not at all in the diabetic patients before C-peptide administration. In addition, an effect of C-peptide on capillary permeability cannot be excluded.

The metabolic effects demonstrated in this study for the exercising forearm during C-peptide treatment in the diabetic subjects are consistent with the earlier findings that C-peptide increases whole body glucose utilization in Type 1 diabetic patients [7,9] and stimulates glucose transport in in vitro incubated human skeletal muscle from Type 1 diabetic patients [10]. The increased glucose uptake in the exercising forearm during C-peptide administration in the diabetic patients is possibly coupled with the increased blood flow and CDC, which may enhance the availability of glucose to the exercising muscles. Insulin does not appear to be responsible for the increased glucose uptake, since not only plasma glucose but also plasma insulin levels were unchanged or tended to decrease when C-peptide was administered. Likewise, both the metabolic and circulatory responses to C-peptide were unrelated to the prevailing blood glucose level. This indicates that the results observed after C-peptide administration are unlikely to be a consequence of the varying degree of hyperglycaemia in the C-peptide and control groups.

The precise mechanism whereby C-peptide stimulated blood flow and increased CDC remains to be determined. In fact, the physiological variables that regulate the functional hyperaemia in skeletal muscle during contraction have not been fully elucidated; for a recent review see [16]. Endothelin, nitrous oxide and adenosine currently appear to be important candidates in this context and it may be speculated that the C-peptide interferes with the formation of one or more of these substances. It is possible that the effects of C-peptide may be exerted via a specific receptor, since there is a significant uptake of this peptide to the forearm tissues in the resting state and a release during exercise. This finding may possibly indicate that C-peptide is bound to receptors in the resting state and subsequently released from the muscle during exercise. Similar findings have been described previously for insulin [17]. A C-peptide receptor in skeletal muscle has not been demonstrated but a specific receptor for homologous Cpeptide has been found in rat Beta cells [18].

The diabetic patients in the present study showed a lower forearm muscle CDC for ${ }^{51} \mathrm{Cr}$-EDTA than the healthy age- and sex-matched control subjects. This is in contrast to the finding by Trap-Jensen and Lassen, who observed higher CDC in the exercising forearm in diabetic patients compared to healthy subjects $[11,12]$. However, Trap-Jensen and Lassen studied older patients with a longer duration of diabetes (mean age 47 years; diabetes duration 21 years). In addition, many of their patients showed clinical signs of diabetic late complications. The latter patient group is thus clearly different from the present relatively young patients without diabetic complications. It is of interest that Trap-Jensen has also reported [19] that in a group of recently diagnosed young diabetic patients the fractional disappearance rate of locally injected ${ }^{51} \mathrm{Cr}$-EDTA from the anterior tibial muscle during ischaemic exercise (another measure of vascular permeability) was significantly lower than in long-term diabetic patients. In fact, in the young diabetic subjects the ${ }^{51} \mathrm{Cr}$-EDTA disappearance rates tended to be even lower than in healthy control subjects [19], in agreement with the present results.

The healthy control subjects in the present study had CDC levels that were almost twice those reported by Trap-Jensen and Lassen $\left(7.7 \mathrm{vs} 3.7 \mathrm{ml} \cdot \mathrm{min}^{-1} \cdot 100 \mathrm{~g}^{-1}\right.$, respectively). The difference primarily concerns extraction of the tracer (31\% in our study and 19\% in Trap-Jensen's study), since blood flow was similar. The discrepancy may have to do with differences in the study procedure and in the choice of subjects. The subjects in our study were young (mean age 21 years) and performed heavy forearm exercise until near exhaustion on a hand ergometer with the hand circulation unoccluded. In the study by TrapJensen and Lassen the healthy control subjects had a mean age of 48 years and the exercise consisted in one full-force flexion of the fingers every second without a specific work load and with a cuff around the wrist to occlude the hand circulation [12]. Thus, the lower CDC levels found in Trap-Jensen's healthy subjects may well be related to the type and intensity of the exercise performed and to the age of the subjects.

It has been demonstrated earlier that C-peptide influences renal function by reducing glomerular hyperfiltration and decreasing urinary albumin excretion in Type 1 diabetes [7,8]. C-peptide also increases glucose utilization [7,9] and improves metabolic control, as evidenced by lowered blood glucose, $\mathrm{HbA}_{\mathrm{lc}}$ and fructosamine [8]. The present study, which demonstrates effects on glucose uptake, blood flow and CDC for ${ }^{51} \mathrm{Cr}$-EDTA in the exercising forearm, lends further support to the notion that C-peptide may be of biological importance in Type 1 diabetic patients, especially with regard to microvascular function and glucose utilization. Our present and previous results and the observation of an inverse correlation between C-peptide levels and late diabetic complications, such as retinopathy $[20,21]$, support the notion that lack of C-peptide may possibly be a contributing factor, in addition to glycaemic control, for the development of microvascular complications in Type 1 diabetes. The mechanisms behind the effects of C-peptide are as yet unclear and further studies will be required to determine the mode of action of C-peptide.

Acknowledgements. Human C-peptide was generously supplied by Eli Lilly Co (Indianapolis, Ind., USA). The study was supported by grants from Novo-Nordisk AB and the Swedish Society of Medicine. 
We are grateful for the expert technical assistance of Ms. A. Ebberyd, Ms. H. Lachmann, Ms. M. Jurkiewicz, Ms. C. Lundberg, Ms. E.L. Olausson, Ms. M. Olsson and Ms. H. Tetzlaff.

\section{References}

1. Steiner DF, Kemmler W, Howard S, Peterson J (1974) Proteolytic processing in the biosynthesis of insulin and other proteins. Fed Proc 33: 2105-2115

2. Steiner D (1978) On the role of the proinsulin C-peptide. Diabetes 27 [Suppl 1]: 145-148

3. Kitabchi AE (1970) The biological and immological properties of pork and beef insulin, proinsulin, and connecting peptides. $J$ Clin Invest 49: 979-987

4. Solomon SS, Brush JS, Kitabchi AE (1970) Antilipolytic activity on ACTH and cyclic nucleotide-induced lipolysis in the isolated adipose cell of rat. Biochem Biophys Acta 218: 167-169

5. Yu SS, Kitabchi AE (1973) Biological activity of insulin and proinsulin and related polypeptides in the fat tissue. $J$ Biol Chem 248: 3753-3761

6. Kitabchi AE (1977) Proinsulin and C-peptide: a review. Metabolism 26: 547-587

7. Johansson B-L, Sjöberg S, Wahren J (1992) The influence of human C-peptide on renal function and glucose utilization in type 1 (insulin-dependent) diabetic patients. Diabetologia 35: $121-128$

8. Johansson B-L, Kernell A, Sjöberg S, Wahren J (1991) Effects of $\mathrm{C}$-peptide on renal function, blood-retinal barrier leakage and metabolic control in type 1 diabetes. Diabetologia 34 [Suppl 2]: A 184 (Abstract)

9. Sjöberg S, Johansson B-L, Östman J, Wahren J (1991) Renal and splanchnic exchange of human biosynthetic C-peptide in type 1 (insulin-dependent) diabetes mellitus. Diabetologia 34: 423-428

10. Zierath JR, Galuska D, Johansson B-L, Wallberg-Henriksson H (1991) Effect of human C-peptide on glucose transport in in vitro incubated human skeletal muscle. Diabetologia 34: 899-901

11. Trap-Jensen J, Lassen NA (1970) Capillary permeability for smaller hydrophilic tracers in exercising muscle in normal man and in patients with long term diabetes. In: Crone C, Lassen NA (eds) Alfred Benzon Symp II. Capillary permeability. Munksgaard, Copenhagen, pp 135 152
12. Trap-Jensen J (1970) Increased capillary permeability to ${ }^{131}$ Iodide and $\left[{ }^{51} \mathrm{Cr}\right] \mathrm{EDTA}$ in the exercising forearm of longterm diabetics. Clin Sci 39: 39 49

13. Garby L, Vuille JC (1961) The amount of trapped plasma in high speed micro-capillary hematocrit centrifuge. Scand J Clin Lab Invest 13: 642-645

14. Heding LG (1975) Radioimmunological determination of human C-peptide in serum. Diabetologia 11: 541-548

15. Arnquist H, Olsson P-O, von Shenk H (1987) Free and total insulin determined after precipitation with polyethylene glycol: analythic characteristics and effects of sample handlings and storage. Clin Chem 33:93-96

16. Persson MG (1991) Studies on metabolic, myogenic, and neurogenic control of skeletal muscle microcirculation. Thesis, Karolinska Institute ISBN 91-628-0418-9

17. Dieterle P, Birkner B, Gmeiner K-H et al. (1973) Release of peripherally stored insulin during acute muscular work in man. Horm Metab Res 5: 316-322

18. Flatt PR, Swanston-Flatt SK, Hampton SM, Bailey CJ, Marks V (1986) Specific binding of the C-peptide of proinsulin to cultured B-cells from a transplantable rat islet cell tumor. Biosci Rep 6: 196-199

19. Trap-Jensen J (1971) Permeability of small vessels in diabetes. Acta Diabet Lat 8 [Suppl 1]: 192-202

20. Sjöberg S, Gjötterberg M, Berglund L, Möller E, Östman J (1991) Residual C-peptide excretion is associated with better longterm glycemic control and slower progress of retinopathy in type 1 (insulin-dependent) diabetes mellitus. J Diab Compl 5: $18-22$

21. Kernell A, Ludvigsson J, Finnström K (1990) Vitreous fluorophotometry in juvenile diabetics with and without retinopathy in relation to metabolic control; Insulin antibodies and C-peptide levels. Acta Opthalmologica 68: 415-420

Received: 15 April 1992

and in revised form: 14 August 1992

Dr. B.-L. Johansson

Department of Clinical Physiology

Karolinska Hospital

P.O. Box 60500

S-104 01 Stockholm

Sweden 